\title{
Bemiddeling na, maar ook voor het openvallen van de nalatenschap van het familiebedrijf
}

\author{
Alain Laurent Verbeke \& Katalien Bollen
}

\begin{abstract}
André (72 jaar) is als mede-eigenaar van het familiebedrijf Goofie een zeer actieve en vermogende ondernemer binnen de internationale koekjes- en wafelindustrie. Hij vertegenwoordigt nu, na het overlijden van zijn twee broers, als enige de tweede generatie binnen de algemene vergadering van aandeelhouders. De neefjes en nichtjes van André, de kinderen van zijn overleden broers, vertegenwoordigen de derde generatie binnen het bedrijf. Daarnaast heeft André de taak van bedrijfsleider overgenomen van zijn vader, de oprichter van het bedrijf. Zijn vrije tijd vult hij in door samen met zijn vrouw Julie te reizen, golfen en zeilen. Vanaf het prille begin is zij heel nauw bij de zaken betrokken geweest. De koekjes en wafels die op vandaag internationaal worden verkocht, zijn gebaseerd op oude familierecepten van Julies grootmoeder. Een aantal jaren geleden, met de komst van de kleinkinderen, besloot Julie het rustiger aan te doen. Ze houdt zich sindsdien voornamelijk bezig met het organiseren van tuinfeesten waar de ganse familie welkom is. Samen met zijn vrouw heeft André drie kinderen: twee zonen, Clément (45 jaar) en Arthur (43 jaar), en een dochter, Marleen (39 jaar). Marleen is net als haar moeder was, het creatieve en culinaire brein binnen het bedrijf. Ze is er sinds geruime tijd werkzaam: zij denkt mee over nieuwe recepten alsook over nieuwe verpakkingsmogelijkheden. Arthur is gepassioneerd door management en is bestuurder van een bank met internationale faam. Ook Clément heeft een carrière buiten het bedrijf en werkt voor een kleine kunstgalerij. Zijn passie voor kunst deelt hij met zijn vader, die door de jaren heen een aanzienlijke collectie van unieke Belgische meesterwerkjes opbouwde. Zoals wel vaker, komt het noodlot uit onverwachte hoek. In maart 2020 wordt André ziek en wat op het eerste gezicht een vieze verkoudheid leek, blijkt achteraf het COVID-19 virus te zijn. Op een week tijd moet de familie van André afscheid nemen. Niemand had kunnen denken dat dit het lot zou zijn van deze sportieve, levenslustige ondernemer.
\end{abstract}

Overlijden, verwacht of onverwacht, is een aangrijpende gebeurtenis. Het kan de familiebanden versterken, maar het kan de familie evengoed verlammen, twijfel zwaaien of sluimerende conflicten laten exploderen. Het gesprek over de toekomst wordt in vele gevallen lang uitgesteld of zelfs helemaal niet gevoerd. Dan loert het familiaal conflict vaak om de hoek en is het vaak een kwestie van tijd tot 
de frustraties, de familie en het familiebedrijf uit hun voegen barsten. Jammer genoeg is het overlijden van de pater familias vaak de negatieve trigger voor een dergelijke uitbarsting van sluimerende conflicten.

Als de familie alles op zijn beloop heeft gelaten tot het overlijden van papa, dan gaan de poppen aan het dansen bij zijn overlijden. Wij bespreken in deze bijdrage kort de juridische afwikkeling van de nalatenschap en daarnaast de alternatieve weg van bemiddeling. Tevens bekijken we wat men anders zou kunnen doen alvorens de nalatenschap is opengevallen. Ook dan is facilitation of bemiddeling een verstandige keuze.

\section{Het openvallen van de nalatenschap: de start van een lange lijdensweg of het alternatief van de bemiddeling?}

\section{De minnelijke weg: een pad bezaaid met potentiële conflicten}

Wanneer bij het overlijden van een familielid-aandeelhouder de aandelen van het familiebedrijf in zijn nalatenschap vallen, zijn deze aanvankelijk in onverdeeldheid tussen de erfgenamen. Het is pas op het ogenblik van de verdeling van de nalatenschap dat elke erfgenaam een concreet en individueel aantal aandelen verkrijgt. ${ }^{1}$ Die verdeling van de nalatenschap (en van de aandelen van het familiebedrijf) is de bron van grote conflicten.

Erfrecht is bloedrecht. ${ }^{2}$ Geschillen in het erfrecht snijden diep, zijn erg intens en emotioneel, geworteld in verre ervaringen en herinneringen uit de jeugd en kindertijd. Ze hebben te maken met frustraties en trauma's die verdrongen en weggesleten zijn, maar vaak niet verwerkt zijn. Nalatenschapsgeschillen kunnen leiden tot familievetes die over generaties heen verder lopen. Vaak is het ego gekwetst, hetgeen gepaard gaat met diepe emoties, wat op zijn beurt algauw kan leiden tot escalatie. ${ }^{3}$

Bij een familiebedrijf is de situatie vaak explosief, door het complexe kluwen van familie, bedrijf en eigenaarschap. ${ }^{4}$ Vertrekkende van deze drie domeinen, die alle nauw met elkaar verweven zijn en overlappen, kunnen verschillende 'groepen' (interest groups) ontstaan met elk hun eigen visie, rol en belang. Zo zijn er de familieleden die eigenaar zijn van het bedrijf, maar niet actief meewerken (de zogenaamde 'family owners'). Dan zijn er familieleden die tewerkgesteld zijn in het familiebedrijf, zonder eigenaar ervan te zijn (ook wel de 'family employees'). Verder zijn er familieleden die tegelijk tewerkgesteld zijn in het familiebedrijf en er eigenaar van zijn (de 'family owner-employees'). Het benaderen van ondernemende families aan de hand van dit 'drie-cirkel-model' (familie, bedrijf en eigenaarschap) is klassiek.

1 J. Du Mongh, De erfovergang van aandelen, NFM 2003, nr. 8, p. 211-217.

2 A.L. Verbeke \& T. Besieux, Mama, waarom zijn wij rijk?, Antwerpen: Intersentia 2015, p. 44; download op http://ssrn.com/abstract=2971595.

3 A.L. Verbeke, Erfrecht en mediation, in: Een decennium nieuw erfrecht, Serie Ars Notariatus 156, Deventer: Kluwer 2014, p. 43-51.

4 R. Tagiuri \& J. Davis, Bivalent attributes of the Family Firm, Family Business Review 1996, 9(2). 


\section{Figuur 1 De tandwielen van een vermogende familie}



Om de systemische complexiteit van een familiebedrijf volledig te vatten, vullen wij dit model aan op twee vlakken. ${ }^{5}$ Daar waar het model van Davis en Tagiuri het familiebedrijf als uitgangspunt hanteert, nemen we de ruimer omvattende familie als uitgangspunt van het model. Die familie vertaalt zich altijd in twee 'sferen': de privésfeer en die van het vermogen. De privésfeer wordt al te vaak vergeten of miskend. Nochtans is de impact daarvan op het dagelijks leven van de familie en haar leden heel groot. De privésfeer omvat alle gewone privéaangelegenheden en de manier waarop de familie met elkaar omgaat: de taal waarmee men spreekt, de manier waarop men elkaar al dan niet aanspreekt en het gemak waarmee men elkaar weet te vinden in geval van nood. Daarnaast maken we binnen de sfeer van het vermogen een onderscheid tussen het bedrijfsvermogen en het investeringsvermogen (zie figuur 1). Een vermogende familie bezit immers ook andere assets naast het familiebedrijf, zelfs wanneer de onderneming zeer dominant is voor de familie. Dit kan gaan om immobiliën of kunst.

Wanneer we de drie tandwielen bekijken (privésfeer, investeringsvermogen en bedrijfsvermogen) en hun onderlinge raakvlakken, dan bekomen we zeven potentiële zones voor conflict (zie figuur 2). Het kan gaan over conflicten die zich uitsluitend situeren binnen één van de drie tandwielen, dan wel in het raakvlak

5 A.L. Verbeke, M. Euwema \& K. Bollen, Familiale grammatica, Antwerpen: Intersentia 2020, p. 102-105. 
Figuur 2 Conflictzones bij vermogende families

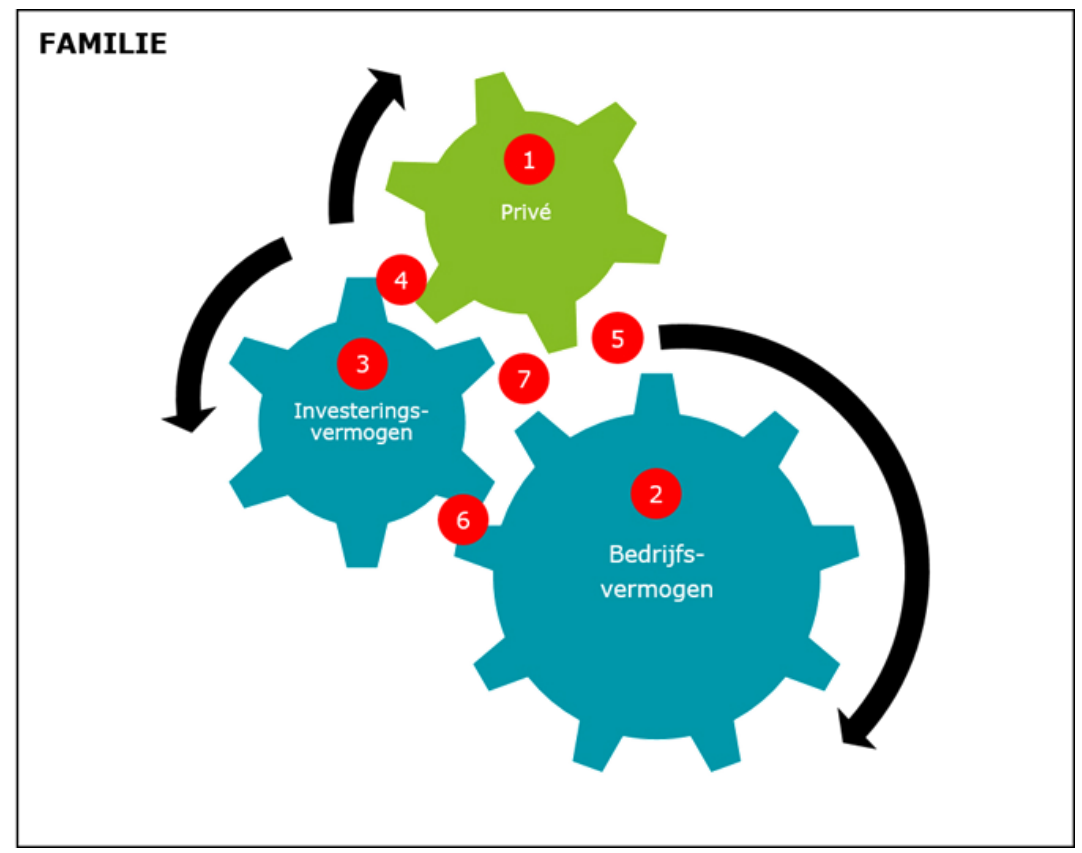

tussen twee of drie tandwielen. ${ }^{6}$ Zo kan het gaan om een louter 'persoonlijk' conflict binnen de privésfeer (omwille van botsende persoonlijkheden of groot verschil in waarden en normen) of om een conflict tussen het raakvlak van investeringsvermogen en bedrijfsvermogen (Investeren we in het bedrijf of beleggen we een deel in kunst?). Heel vaak zie je dat een conflict gesitueerd in één gebied zich na verloop van tijd uitspreidt en ook andere gebieden begint te beïnvloeden. Vandaar het belang om conflicten tijdig aan te pakken of te voorkomen. In de praktijk spreekt men meestal over taakconflicten die gaan over de manier waarop het werk wordt uitgevoerd, en relationele conflicten die gaan over de relatie met de ander. Onderzoek toont aan dat relationele conflicten vaak zwaarder doorwegen dan taakconflicten en dat taakconflicten evolueren naar relationele conflicten indien er niet tijdig wordt geïntervenieerd. Aldus is een vermogende familie een opmerkelijk complex systeem waarbij de verschillende scharnierpunten aanleiding kunnen geven tot conflict. In de conflictliteratuur maakt men een onderscheid naar vier soorten conflict: taakconflicten, procesconflicten, relatieconflicten en statusconflicten. ${ }^{7}$

6 A.L. Verbeke \& K. Bollen, Potentiële conflicten bij vermogende families, Deloitte Legal Newsflash, April 2020. K.A. Jehn \& E.A. Mannix, The dynamic nature of conflict: A longitudinal study of intragroup conflict and group performance, Academy of Management Journal 2001, 44(2), p. 238-251.

7 K.A. Jehn \& E.A. Mannix, The dynamic nature of conflict: A longitudinal study of intragroup conflict and group performance, Academy of Management Journal 2001, 44(2), p. 238-251. 
Een veel gebruikte manier om conflictstijlen en -gedrag in te delen is het duale zorgmodel, dat gebaseerd is op twee dimensies. ${ }^{8}$ Er zijn twee dimensies aan conflicthantering: zorg voor jezelf en je eigen visie versus zorg voor de ander of voor de relatie met de ander. Vandaar de term 'duale zorg'. ${ }^{9}$ Bij de conflictstijl van vermijden is zowel de zorg voor je eigen zaak als die voor de ander niet groot. Men hoopt dat het de volgende dag wel beter zal zijn. Bij de conflictstijl van toegeven heb je vooral oog voor de behoeften en belangen van de ander. De relatie met de ander primeert op de eigen wensen en behoeften. Dit maakt waarom men regelmatig toegeeft aan de pater familias: men dient hem te respecteren en te luisteren, want hij heeft het bedrijf gemaakt tot wat het vandaag is. Dat niet doen, is een schande en niet respectvol. Het feit dat de traditionele Vlaamse familie vaak gekenmerkt wordt als hiërarchisch of paternalistisch draagt hier zeker toe bij. ${ }^{10}$ Deze dynamiek maakt het moeilijk om latente frustraties en gevoelens te uiten. Hierdoor wordt het steeds moeilijker om het conflict ter sprake te brengen, want 'waar is het nu weer allemaal begonnen?'11 Twee andere stijlen die in dit model benoemd worden, zijn forceren waarbij de zorg voor de eigen zaak vooropstaat en samenwerken waarbij zowel de zorg voor de eigen zaak als die van de ander centraal staan. Het moge duidelijk zijn dat efficiënt en constructief conflictgedrag zich kenmerkt door het gebruik van een conflictstijl die past bij het issue dat ter discussie staat: vermijden als iets er écht niet toe doet, probleemoplossend te werk gaan als het een issue is dat voor iedereen belangrijk is nu en op de lange termijn.

Uit onderzoek blijkt dat familiale conflicten vooral uitbarsten of duidelijk worden wanneer er verschuivingen optreden en familieleden andere posities of rollen (moeten) opnemen, hetgeen veelal het geval is bij een overlijden. Men grijpt dan terug naar ervaringen uit het verleden en bijbehorende frustraties die tot dan toe werden verdrongen. Gevoelens van miskenning en jaloezie blijven decennialang hangen. Bij de discussie over de verdeling van de nalatenschap komen deze gevoelens maar al te vaak als een boemerang terug naar boven. ${ }^{12}$

8 A.L. Verbeke, M. Euwema \& K. Bollen, Familiale grammatica, Antwerpen: Intersentia 2020, p. $79-82$.

9 G. Richard Shell, Bargaining Styles and Negotiation: The Thomas-Kilmann Conflict Mode Instrument in Negotiation Training, Harvard, Negotiation Journal 2001, p. 155-174; J.L. Holt \& C.J. Devore, Culture, gender, organizational role, and styles of conflict resolution: A meta-analysis, International Journal of Intercultural Relations 2005, 29(2), p. 165-196.

10 A. Verbeke \& T. Besieux, Generatieconflicten bij vermogende families, Nederlands-Vlaams Tijdschrift voor Mediation en conflictmanagement, 2016, 20(2), p. 6-22.

11 Tegelijkertijd zijn deze frustraties en bekommernissen niet minder reëel, want hoe sterker we onderling verbonden zijn, zowel emotioneel in ons dagelijks leven, in ons werk als in financiële en materiële zin, hoe meer het potentieel voor conflict toeneemt. Dat is de paradox van de vermogende familie. Hoe sterker we onderling verbonden zijn, hoe meer er op het spel staat en hoe meer zaken er zijn waarover conflicten kunnen ontstaan.

12 A.L. Verbeke, M. Euwema \& K. Bollen, Familiale grammatica, Antwerpen: Intersentia 2020, p. 88-89. 
De gerechtelijke weg: een route met vele vluchtwegen

\begin{abstract}
Bij het regelen van de begrafenis van André komen de eerste spanningen al naar boven. Clément meent dat het zijn vaders wens was om een christelijke uitvaart te hebben in aanwezigheid van al zijn kennissen. Arthur en Marleen zijn het hier niet mee eens en zeggen dat 'zoiets niet meer van deze tijd is'. Het conflict over waarden en normen breidt zich al snel uit als het punt van de nalatenschap ter sprake komt. Marleen is bang dat Arthur de leiding van het bedrijf zal overnemen en dat hij vervolgens grote herstructureringen zal doorvoeren. Clément is bang dat zijn broer en zus de kunstwerken van vader, die hij zo koesterde, zullen verkopen. De gemoederen laaien zo hoog op, dat Arthur uiteindelijk zijn advocaat raadpleegt, waarop de zaak voor de rechter wordt gebracht. De gerechtelijke vereffening-verdeling sleept aan en wat de aandelen betreft, krijgen Clément, Arthur en Marleen elk een gelijk deel. Ook de kunstcollectie wordt onder de drie kinderen gelijk verdeeld.

Sinds het overlijden van André gaan de cijfers van het familiebedrijf er sterk op achteruit. De aandeelhoudersvergaderingen draaien in veel gevallen uit op zware discussies tussen de drie kinderen van André. In veel gevallen is Clément als aandeelhouder afwezig; het familiebedrijf heeft hem toch nooit echt geïnteresseerd. Verder hebben Marleen en Arthur de kunstwerken die aan hen zijn toebedeeld al snel tegen een spotprijsje verkocht.
\end{abstract}

Wanneer men nooit heeft geleerd om op een constructieve manier met familiaal conflict om te gaan, is de stress des te groter wanneer men als familie geconfronteerd wordt met pijnlijke gebeurtenissen zoals het (onverwacht) overlijden van de pater familias. In die gevallen is het vermijden van een gesprek en meningsverschillen geen optie. Er dienen zaken besproken en geregeld te worden. Lukt dat niet met elkaar, dan lijkt meestal maar één oplossing mogelijk: het raadplegen van een advocaat die het conflict aan de rechter voorlegt. Echter, een gerechtelijke procedure kan lang aanslepen, wat niet alleen gepaard gaat met hoge kosten en stress, maar ook polarisering en bijgevolg verdere escalatie in de hand werkt. Ook de wetgever heeft dit ingezien en stimuleert alternatieve vormen van geschiloplossing zoals bemiddeling.

De advocaat is vaak de eerste persoon tot wie de cliënt zich richt wanneer men niet meer weet hoe het verder moet met een bepaald conflict. Het is de taak van de advocaat de rechtzoekende te informeren over de alternatieven om het geschil op te lossen. ${ }^{13,14}$ Ook de rechter moet bij de aanvang van een gerechtelijke ver-

14 A.L. Verbeke \& G. Vervaeke, Onderhandelen en bemiddelen: Een praktische inleiding, Antwerpen: Intersentia 2020 (studenteneditie), p. 41-43; V. Lesseliers, 7 redenen waarom de nieuwe wet op de bemiddeling belangrijk is voor het notariaat, T.Not., 2019(3), p. 220. 
effening-verdeling een minnelijke oplossing van het geschil promoten. ${ }^{15}$, 16 Hij moet de partijen op de inleidingszitting bevragen over de manier waarop zij voordien hebben geprobeerd om een minnelijke oplossing te bereiken. Hij kan daartoe de verplichte persoonlijke verschijning van de partijen bevelen. ${ }^{17}$ Of hij kan de zaak verdagen naar een latere datum en de partijen bevelen een bemiddeling aan te vatten. Deze maatregel kan worden bevolen op verzoek van een van de partijen of op initiatief van de rechter wanneer hij vaststelt dat verzoening mogelijk is. ${ }^{18}$ In familiezaken is het bovendien mogelijk dat de familierechter de partijen ambtshalve doorverwijst naar de kamer voor minnelijke schikking en dit telkens wanneer hij dat nuttig acht. Dit wil niet zeggen dat de daadwerkelijke poging tot minnelijke schikking kan worden opgedrongen. ${ }^{19,} 20$

Stelt de rechter vast dat geen verzoening mogelijk is en dat de gerechtelijke vereffening en verdeling moet worden verdergezet, dan is het niet hijzelf die de hele verdeling verwezenlijkt. Hij verwijst de partijen door naar een door hem aangewezen notaris (boedelnotaris of notaris-vereffenaar). De notaris krijgt dan de opdracht om tot de vereffening-verdeling over te gaan. ${ }^{21,} 22$

Deze notariële fase kent verschillende tussenstappen. Het al dan niet vlotte verloop ervan hangt in grote mate af van de houding van de partijen. Het feit dat de 'zaak' reeds aan de rechter werd voorgelegd, voorspelt vaak weinig goeds. Zeer dikwijls zijn verschillende familieleden niet in staat om tot een minnelijk akkoord te komen. Vaak zitten zij vast in emoties en positionele claims. In de hoop partijen toch tot een akkoord te brengen, is aan de notaris een bemiddelende en verzoenende taak opgelegd. ${ }^{23}$ De notaris dient zich op te stellen als een onpartijdige vereffenaar die tracht de werkzaamheden positief bij te sturen daar waar zij dreigen te ontsporen. De notaris is niet alleen de deskundige om de procedure op familiaal-vermogensrechtelijk vlak te regelen, maar is omwille van zijn ervaring met dergelijke situaties mogelijks ook een goede conflictbemiddelaar. Deze taak is een rode draad doorheen de vereffening-verdeling. ${ }^{24}$

De procedure bij de notaris start zodra een partij de notaris verzoekt om de werkzaamheden aan te vatten. De notaris nodigt de verschillende partijen uit voor een eerste bijeenkomst: de opening van de werkzaamheden. Tijdens deze opening van de werkzaamheden, maakt de notaris een eerste overzicht van de situatie. Het doel van deze eerste zitting is om alle inlichtingen en stukken te verkrijgen die

15 Art. 730/1, §1 Ger.W.

16 A.S. D'Herde \& A.L. Verbeke, De rol van de rechter bij bemiddeling in familiezaken, in: Liber amicorum P. Senaeve, Deventer: Wolters Kluwer 2017, p. 551-583.

17 Art.730/1, § 2, lid 1 Ger.W. en art. 1253ter/3, § 1, lid 2 Ger.W.

18 Art. 730/1, § 2, lid 2 Ger.W. en 1734, §1, lid 2 Ger.W.

19 Art. 1253ter/1, § 3, lid 2 Ger.W.

20 Art. 1253ter/1, § 3, lid 2 Ger.W, de poging tot minnelijke schikking kan ook onder het nieuwe recht principieel niet verplicht worden gesteld (art. 731 Ger.W.).

21 Art. 1210 Ger.W.

22 H. Casman, Vereffening-verdeling 2013-2014 (studenteneditie), Herentals: Knops Publishing 2014.

23 Art. 1214 §1, Ger.W. \& art. 10 en 39 van de deontologische code.

24 B. Van Den Berghe, Wie is er bang van de actieve notaris-vereffenaar, Tendensen vermogensrecht 2018, Antwerpen: Intersentia 2018, p. 121-123. 
nuttig zijn voor het vervullen van de opdracht. ${ }^{25}$ Gedurende de vergadering wordt ook besproken of een boedelbeschrijving noodzakelijk is. Dan wordt een foto gemaakt van de omvang en samenstelling van de boedel, van de verklaringen van partijen over en weer. De afsluiting met een eed van elke partij dat ze niets verzwegen of verduisterd hebben, draagt bij tot de bewijskracht van de boedelbeschrijving. Tijdens de eerste vergadering wordt ook het tijdschema voor het verdere verloop van de gerechtelijke verdeling besproken. De wet voorziet in een vast stramien waarbinnen de verschillende stappen in de procedure dienen te gebeuren ('de wettelijke instaatstelling'), maar laat de partijen ook de vrijheid om zelf, in samenspraak met de notaris, een kalender vast te stellen ('de conventionele instaatstelling'). Een andere mogelijkheid die de wet biedt, is om de procedure zonder bindende termijnen te laten verlopen. Komen de partijen niet tot een akkoord, dan gelden de wettelijke termijnen waarvan opnieuw afgeweken kan worden indien partijen alsnog tot een akkoord komen. ${ }^{26}$ Aan het einde van deze bijeenkomst wordt een proces-verbaal van opening werkzaamheden opgemaakt waarin alle afspraken vastliggen. ${ }^{27}$

Nadat het proces-verbaal van opening werkzaamheden, de eventuele processenverbaal van voortzetting van werkzaamheden en eventueel de boedelbeschrijving zijn afgewerkt, krijgen de partijen een termijn om hun aanspraken mee te delen. ${ }^{28}$ Ze omschrijven hun eigen claims en nemen een standpunt in omtrent de vorderingen van de andere partijen. ${ }^{29}$ De partijen moeten ook een kopie bezorgen aan de notaris-vereffenaar en de andere partijen van de stukken die zij willen aanwenden. Eens de notaris over alle relevante informatie beschikt, gaat hij over tot de opmaak van een overzicht van aanspraken. Dit wordt aan de partijen en hun advocaten bezorgd, waarop zij vervolgens hun opmerkingen mogen meedelen.

Vervolgens maakt de notaris een ontwerp van verdeling op in een staat van vereffening. ${ }^{30}$ Dit legt hij voor aan de partijen die hun eventuele bezwaren kunnen formuleren. ${ }^{31}$ Gebeurt dit niet, dan is het voorstel van de notaris goedgekeurd en kan hij de kavels toewijzen. Tot slot wordt het proces-verbaal van sluiting opgesteld, waardoor de verdeling definitief is en de nalatenschap, met hulp van de notaris, minnelijk is verdeeld. ${ }^{32}$ Zijn er echter geldige bezwaren ingediend, dan kan de notaris de werkzaamheden niet sluiten. In dat geval zal hij een proces-verbaal van geschillen en moeilijkheden opmaken. Hij moet de bezwaren beoordelen en een schriftelijk advies geven aan de rechter over de gerezen geschillen en moeilijkheden. Na de partijen te hebben gehoord, kan de rechter de geschillen en moeilijkheden beslechten. ${ }^{33}$ die Keure 2012, p. 126.

Art. 1218, §3 Ger.W.

Art. 1223 Ger.W.

Art. 1223, §2 Ger.W.

Art. 1223, §3 en $\S 4$ Ger.W. 
Ofwel keurt de rechter (in eerste aanleg of in beroep) de staat van vereffening en het ontwerp van verdeling goed (homologatie). De notaris roept dan de partijen op zodat de concrete verdeling kan plaatsvinden. ${ }^{34}$ Ingeval de rechtbank of het Hof van Beroep niet akkoord gaat met de staat van vereffening en het ontwerp van verdeling, wordt de zaak terug naar de notaris-vereffenaar gezonden. In dat geval moet hij, conform de richtlijnen van de rechter, een aanvullende of aangepaste staat opmaken, met een aangepast ontwerp van verdeling. Worden opnieuw bezwaren geuit, dan moeten deze wederom, na advies door de notaris, worden voorgelegd aan de rechter. ${ }^{35}$ Indien er geen bezwaren zijn, maakt de notaris een proces-verbaal van sluiting op, waarna de toebedeling kan worden uitgevoerd. ${ }^{36}$

\section{De gulden middenweg: de piste van de alternatieve geschillenoplossing}

Een gerechtelijke vereffening en verdeling is niet de meest aangewezen piste om familiale stabiliteit en duurzaam ondernemerschap te garanderen. In een gerechtelijke procedure gaat het vaak enkel om het 'beslechten' van een juridisch geschil en niet om het 'oplossen' van een dieperliggend conflict. Familieleden krijgen zelden waar ze op hadden gehoopt: erkenning, respect, waardering, het gevoel dat er rekening werd gehouden met gevoelens en wensen. ${ }^{37}, 38$

Wil men streven naar conflictoplossing met een duurzaam karakter, dan is het van belang gehoor te geven aan deze roep naar erkenning en respect. Het is noodzakelijk de ander te beluisteren en ook zelf aan te geven waar het schoentje knelt. Dit proces is breder dan enkel de punctuele kwesties in een dossier van vereffening en verdeling. Men tracht een oplossing te vinden voor het bredere relationele conflict en niet enkel voor het concrete (juridische) geschil. ${ }^{39}$ Hiervoor is geduld en inspanning nodig, maar ook reflectie en constructieve communicatie. Dit vraagt veel van families, en familieleden zitten vaak veel te diep in de familiedynamiek om het overzicht te bewaren of missen het geduld om de andere familieleden zonder vooroordelen of verwachtingen te bevragen. Dit maakt dat de ondersteuning van een bemiddelaar of van experten in family dynamics vaak noodzakelijk is. ${ }^{40}$

'Bemiddeling' is een vertrouwelijk en gestructureerd proces van vrijwillig overleg tussen conflicterende partijen dat gefaciliteerd wordt door een onafhankelijke, neutrale en onpartijdige derde ('de bemiddelaar'). De bemiddelaar poogt de communicatie te vergemakkelijken om zodoende de partijen ertoe te brengen zelf een

34 Art. 1223, §5 Ger.W

35 Art. 1223, §6 Ger.W.

36 H. Casman, Vereffening-verdeling 2013-2014 (studenteneditie), Herentals: Knops Publishing 2014.

37 K. Bollen, H. Ittner \& M.C. Euwema, Mediating hierarchical labor conflicts: Procedural justice makes a difference - for subordinates, Group Decision and Negotiation, 2012, 21(5), p. 621-636.

38 K. Bollen, M. C. Euwema \& L. Munduate (ed.), Advancing workplace mediation through integration of theory and practice, London: Springer International Publishing 2016.

39 E. Lancksweerdt, Waar zorg en recht elkaar ontmoeten. De multi-disciplinaire aanpak van scheidingsconflicten, T.Fam. 2018, p. 186.

40 A.L. Verbeke, M. Euwema \& K. Bollen, Familiale grammatica, Antwerpen: Intersentia 2020, p. 92-94. 
oplossing uit te werken. ${ }^{41},{ }^{42}$ Daarnaast is bemiddeling een consensueel proces, waarin men zich vrijwillig engageert. Bij court ordered mediation zal het engagement om ermee te beginnen niet noodzakelijk vrijwillig zijn, maar het blijvend participeren wel. ${ }^{43}$ Partijen kunnen afhaken wanneer zij dat willen zonder motivering (met enige nuancering bij court ordered mediation). Dit is het zelfbeschikkingsrecht van de partijen.

Daarnaast is de bemiddelaar meerzijdig partijdig, hetgeen inhoudt dat hij partijdig is of kan zijn voor elke partij. Samen met de conflicterende partijen gaat de bemiddelaar op zoek naar de achterliggende belangen. Men zoekt een oplossing voor problemen of conflicten op basis van wederzijds akkoord en billijkheid voor alle partijen. Een afzonderlijk gesprek met de bemiddelaar (caucus) is mogelijk, maar onder strikte voorwaarden. ${ }^{44}$ Finaal is het de bedoeling dat partijen zelf tot een oplossing komen. Wanneer partijen tot overeenkomsten komen die ze zelf onderhandeld hebben, dan is de kans veel groter dat die overeenkomst door hen zal worden nageleefd. Ze kennen en begrijpen de elementen en overwegingen waarmee rekening werd gehouden om tot een welbepaalde oplossing te komen, terwijl men bij een rechterlijke beslissing dikwijls de juridische overwegingen niet begrijpt, wat het veel moeilijker maakt om zich daarbij neer te leggen.

Deze kenmerken van bemiddeling kunnen worden samengevat in het eenvoudige acroniem VCAM: Vrijwilligheid, Confidentialiteit, Autonomie en Meerzijdige partijdigheid. ${ }^{45}$

Vooral in situaties waar partijen elkaar nog na het conflict zullen zien en harmonieus wensen samen te leven of de verstandhouding willen bestendigen, is bemiddeling een belangrijke tool. Dat is natuurlijk bij uitstek het geval bij de vereffening-verdeling van een nalatenschap waar de partijen (bloed)verwanten zijn van elkaar.

Er kan voor bemiddeling geopteerd worden voorafgaand, tijdens of zelfs na de gerechtelijke vereffening-verdeling. Als via bemiddeling niet tot een akkoord kan gekomen worden en de nalatenschap toch nog via een gerechtelijke weg wordt vereffend en verdeeld, wordt de vereiste van de vertrouwelijkheid van de bemiddeling zeer duidelijk. Documenten en mededelingen gedaan in de loop van de bemiddelingsprocedure kunnen niet worden meegedeeld in de gerechtelijke procedure. $^{46}$

41 Art. 1723/1 Ger.W.

42 B. Van Den Berghe, Wie is er bang van de actieve notaris-vereffenaar, Tendensen vermogensrecht 2018, p. 121-123; K. Bollen \& M. Euwema, Macht en emoties in conflict (bemiddeling), Tijdschrift conflicthantering 2012, p. 4-7; A.L. Verbeke \& G. Vervaeke, Onderhandelen en bemiddelen: Een praktische inleiding, Antwerpen: Intersentia 2020 (studenteneditie).

43 Ibid.

44 A.L. Verbeke, Mediation, faciliteren van onderhandelingen, in: Reflectie op mediation, Antwerpen: Maklu 2009, p. 27-46 (http://ssrn.com/abstract=1751676).

45 A.L. Verbeke, Bemiddeling, het nieuwe Esperanto, Interview Kanaal Z, volledige versie en verkorte versie op Z Legal 8 mei 2020, zie www.law.kuleuven.be/fvr/nl/nieuws/z-legal-kanaal-zinterview-over-bemiddeling-en-de-troeven-daarvan.

46 A.S. D’Herde \& A.L. Verbeke, Bemiddelen in vertrouwen, in: Verantwoord aansprakelijkheidsrecht. Liber amicorum A. Van Oevelen, Antwerpen: Intersentia 2017, p. 263-294. 
Als de bemiddelaar in het raam van een nalatenschap een jurist is, kan de neiging ontstaan om in te gaan op de inhoudelijke juridisch-technische aspecten van de discussies. Bargaining gebeurt altijd in de shadow of the law. ${ }^{47}$ Echter, de essentie van bemiddeling is faciliterend. Faciliterende bemiddeling wordt vaak beschouwd als de klassieke bemiddeling. Hier is het niet louter van belang een overeenkomst te bereiken, maar ook het zoeken naar een beter begrip tussen de partijen. De faciliterende bemiddelaar wil ervoor zorgen dat de partijen op een creatieve wijze alle mogelijkheden exploreren. De bedoeling is dat een eventueel akkoord optimaal beantwoordt aan de belangen van de partijen en daardoor ook duurzamer is. De bemiddelaar beperkt zich tot het faciliteren van communicatie en de onderhandelingen tussen partijen. Kortom, de faciliterende bemiddelaar helpt partijen een oplossing te vinden voor het conflict die beide partijen recht doet en die de relatie voldoende in rekening brengt. ${ }^{48}$ Evaluerende bemiddeling daarentegen, is gericht op het vinden van een oplossing. In dit type van bemiddeling kan de bemiddelaar zelf oplossingen aanreiken en advies geven. Hij stuurt de partijen in de richting van een oplossing. Indien partijen bewust en expliciet vragen om advies van de bemiddelaar, dan kan de bemiddelaar diverse pistes vanuit zijn juridische expertise helpen evalueren. Hier functioneert de bemiddelaar veeleer als een semi-arbiter. Hoewel hij geen formeel bindende beslissingsbevoegdheid heeft, probeert hij met overtuigingskracht de partijen te sturen in de richting van een oplossing die hij haalbaar acht. Typisch is dat die oplossing vaak in de lijn ligt van het juridisch systeem, van wat wellicht door een rechter zou worden beslist. Men kan daar nog een stapje verder in gaan en de bemiddelaar een soort van case settlement-opdracht geven. Dan zal hij als een neutrale onderhandelaar met elk van de partijen in onderhandeling gaan, de juridische pro's en contra's tegen elkaar afwegen en proberen te komen tot een akkoord. In de Verenigde Staten gebeurt mediation vaak op deze manier. Daar is niets fout mee, maar het is wel van belang dat men inziet dat de bemiddelaar daarmee het strikte proces van de bemiddeling pur sang verlaat. ${ }^{49}$

\section{Bemiddelen voordat de nalatenschap openvalt}

Het familiaal leerproces: conflictvaardigheden aanleren
Ze hebben het er nog nooit expliciet over gehad, maar André wil dat na zijn overlijden alles gelijk wordt verdeeld onder zijn drie kinderen: de aandelen, de schilderijen, enzovoort. Wat de rollen binnen het familiebedrijf betreft ziet André enkel Marleen als een mogelijke opvolger binnen het familiebedrijf (onder

47 R.H. Mookin \& Kornhauser, Bargaining in the Shadow of the Law: the Case of Divorce, Yale LJ 1979, p. 950 e.v.; A.L. Verbeke, Leer advocaten probleemoplossend onderhandelen, Tijdschrift voor Conflicthantering 2014, nr. 5, p. 35-38.

48 A.L. Verbeke, Mediation, faciliteren van onderhandelingen, in: Reflectie op mediation, Antwerpen: Maklu 2009, p. 27-46 (http://ssrn.com/abstract=1751676).

Ibid. 
meer omdat ze nu reeds in het bedrijf actief is). Clément heeft volgens André niet de nodige vaardigheden om een rol binnen de bedrijfswereld op te nemen en Arthur heeft de job van zijn leven bij de bank.

André heeft een sterke visie en daadkracht, maar open communicatie is een minder sterke kant. Bijgevolg delen de kinderen hun onzekerheden en twijfels eerder met hun moeder Julie. Zo heeft Arthur haar toevertrouwd dat de job bij de bank niet is waar hij van droomde en dat hij liever mee het familiebedrijf zou uitbouwen. En Marleen heeft laten weten dat ze niets moet weten van die meetings en strategische beslissingen. Het liefste wat ze doet, is recepten bedenken, zonder de leiding te moeten nemen. En van Clément weet eigenlijk niemand waar hij mee bezig is; 'iets creatiefs'.

Julie stelt voor om hulp te vragen bij een expert in family \& business dynamics, om zo het gesprek in de familie over de toekomst te faciliteren. Thuis worden deze thema's niet openlijk besproken en ligt feedback geven aan elkaar moeilijk. Julie heeft schrik voor de dag dat de drie kinderen het met elkaar zullen moeten gaan doen. Ze praten nu al nauwelijks met elkaar. En in geval van conflict wachten ze meestal tot het overwaait of luchten ze hun hart bij Julie, al dan niet in de hoop dat zij er wat mee doet. Hoe zal dat gaan wanneer beide ouders overleden zijn?

Het is goed te leren aanvaarden dat conflicten deel uitmaken van wie we zijn. Cruciaal is te beseffen dat ze ons een kans bieden om na te denken, te groeien als mens en als familie in haar geheel. Conflicten zijn een bron van energie waarmee op een constructieve manier kan worden omgegaan. Dit vereist dat men leert het op een constructieve manier met elkaar oneens te zijn en de dialoog hierover aan te gaan, in alle openheid. ${ }^{50}$ Het is belangrijk om als familie zo vroeg mogelijk te werken aan de conflictvaardigheid van de familieleden afzonderlijk en van de familie als geheel. Die vaardigheid bestaat uit zelfkennis, voeling met bepaalde familiale waarden en belangen alsook goede communicatievaardigheden: hoe kan ik op een empathische manier de ander beluisteren? ${ }^{51}$ Dit kan door actief te luisteren, waarbij men de eigen innerlijke stem stil legt om zo maximaal de aandacht aan de ander te besteden. Hoe men dat doet? Door (a) het stellen van open vragen en door te vragen, (b) door na te gaan of men de ander wel goed heeft begrepen door middel van te parafraseren (namelijk wat men heeft begrepen in eigen woorden herformuleren) en (c) het (h)erkennen van gevoelens van de ander. ${ }^{52}$ Investeringen in transparante communicatie en conflictvaardigheid kunnen op die manier conflicten voorkomen of ertoe bijdragen dat conflicten op een con-

50 A.L. Verbeke \& K. Bollen, Potentiële conflicten bij vermogende families, Deloitte Legal Newsflash, April 2020.

51 A.L. Verbeke, M. Euwema \& K. Bollen, Familiale grammatica, Antwerpen: Intersentia 2020, p. 89-90.

52 A.L. Verbeke \& G. Vervaeke, Onderhandelen en bemiddelen: Een praktische inleiding, Antwerpen-Cambridge: Intersentia 2020 (studenteneditie), p. 25-26. 
structieve manier worden opgelost. Ook bij overlijden van de pater familias kan dit de problemen enorm beperken. ${ }^{53}$ Daarnaast draagt deze transparante communicatie bij tot het expliciteren van verwachtingen, wat leidt tot duurzame oplossingen en duurzaam aandeelhouderschap ten goede komt.

Dit vereist een familiaal leerproces. Om dit als familie meteen zelf op te pakken is meestal uitdagend en moeilijk. Een facilitator die als kritische partner van buitenaf de familie begeleidt en zo bijdraagt aan reflectie in en over de familie en haar familieleden, kan families op weg zetten. Wie een dergelijk familiegroeiproces faciliteert, dient de vaardigheden, technieken, attitude en ethiek te hanteren van een kwaliteitsvolle bemiddelaar. ${ }^{54}$ Het doel van het proces bestaat erin dat de familieleden er gaandeweg in slagen om constructief en empathisch naar elkaar te luisteren en kijken. Zo beschikken zij over de nodige conflictvaardigheden om op een open en positieve manier met conflicten en discussies om te gaan en om ze uiteindelijk zelf(s) op te lossen. ${ }^{55}$ Indien alle familieleden zich hiertoe engageren, is dit de beste garantie voor verstandhouding nu en op de lange termijn. Naarmate de familieleden beter in staat zijn om constructief om te gaan met relatief eenvoudige en kleine meningsverschillen, ontwikkelen ze de vaardigheid om ook beter om te gaan met complexe uitdagingen zoals de vererving of de regeling van bestuur van het vermogen. ${ }^{56}$ Het samen als familie op weg gaan, luisteren naar en praten met elkaar is de essentie van het familiaal leer- en groeiproces (family dynamics) en de sleutel bij ieder conflict.

\section{De nalatenschap regelen voor ze openvalt}

Een manier om conflicten bij het openvallen van de nalatenschap te vermijden, is ervoor te zorgen dat het vermogen op een degelijke manier is geregeld voor het overlijden, niet enkel juridisch of fiscaal, maar vooral ook emotioneel en menselijk. Als eenieder zijn rol en plek vindt binnen de familie en het vermogen, kunnen familieleden samen aan de kar trekken als verantwoordelijke en duurzame aandeelhouders. Familiale dialoog en reflectie zijn noodzakelijk, zodat de familiale visie en het commitment van eenieder duidelijk worden. Familieleden die met elkaar in gesprek gaan over hun verwachtingen en onderliggende belangen, nemen beslissingen die gedragen worden door alle familieleden, duurzaam doorheen de tijd.

In een eerste fase is het belangrijk dat een familie zich voorbereidt om met elkaar in gesprek te gaan. Dit impliceert het aanleren van de genoemde communicatieen conflictvaardigheden. Daarnaast is het belangrijk dat familieleden op een

53 A.L. Verbeke, M. Euwema \& K. Bollen, Familiale grammatica, Antwerpen: Intersentia 2020; A.L. Verbeke \& T. Besieux, Mama waarom zijn wij rijk? Multidisciplinair en systemisch onderzoek naar familievermogen, Antwerpen-Cambridge: Intersentia 2015 (http://ssrn.com/abstract =2971595).

54 A.L. Verbeke, Bemiddelen voor het geschil: Family Governance, Tijdschrift voor Privaatrecht 2014, p. 969-982.

55 A.L. Verbeke \& K. Bollen, Potentiële conflicten bij vermogende families, Deloitte Legal Newsflash, April 2020.

56 A.L. Verbeke, M. Euwema \& K. Bollen, Familiale grammatica, Antwerpen: Intersentia 2020, p. 89-90. 
actieve manier naar elkaar kunnen en willen luisteren en empathie tonen aan elkaar. Laat men weinig ruimte voor inspraak of het bespreken van tegenstellingen, dan krijgen familieleden het gevoel dat ze niet gezien of erkend worden. ${ }^{57}$ Eenmaal een basis is gelegd voor deze vaardigheden, kan de familie in een tweede fase een traject ingaan. Deze tweede fase is eigenlijk een proces van familiale 'onderhandelingen', onderhandelingen over waar men als gezin en familie naartoe wil: de gedeelde waarden, de vertaling daarvan in omgangsprincipes of gedrag, duidelijke rollen, heldere governance-regels en afspraken. Klassiek worden die vastgelegd in een familiecharter. Wij verkiezen de term familiekompas: het geeft de richting aan, maar is niet statisch. Het is flexibel en kan de familie gidsen op woelige wateren en veranderende omstandigheden. ${ }^{58}$

Pas wanneer deze fasen doorlopen zijn, is een familie ook echt klaar om in de derde fase een doordachte, ingebedde en volledig gedragen juridische en fiscale planning uit te rollen. ${ }^{59}$ Daarbij is de nieuwigheid van het hervormde erfrecht van 2018, de globale erfovereenkomst (GEO) of het pact familial een nuttig instrument (art. 1100/7 BW). Dit pact wordt gesloten tussen een of beide ouders met alle kinderen teneinde een evenwicht vast te stellen tussen de 'vermoedelijke erfgenamen in rechte neerdalende lijn'. Voor het bepalen van het evenwicht kan rekening worden gehouden met vijf elementen:

1 reeds gedane schenkingen, in het verleden, dus voor het afsluiten van de globale erfovereenkomst;

2 nieuwe schenkingen toegekend in de globale erfovereenkomst zelf;

3 de 'situatie' van elk van de kinderen, bijvoorbeeld een beperking of bepaalde moeilijkheden in het leven;

4 voordelen die partijen met schenkingen gelijkstellen. Denk bijvoorbeeld aan dienstengiften, het voordeel dat één van de kinderen vele jaren genoot omdat de ouders kosteloos allerlei diensten verstrekten in het huishouden, de woning, de kinderzorg, of hun kosteloze huisvesting verstrekten;

5 schuldvorderingen, die al dan niet meteen opeisbaar zijn. ${ }^{60}$

De wetgever heeft bewust gekozen voor een overeenkomst die geen gelijkheid maar evenwicht realiseert. Dit is geen strak juridisch-mathematisch begrip, maar een subjectief concept. Het gaat erom dat familieleden bepalen wat specifiek voor hen eerlijk, rechtvaardig, billijk is, rekening houdend met de persoonlijke, concrete situatie (vermogen, capaciteit, talent, beperkingen, enz.) van elke vermoedelijke erfgenaam. Maar hoe kan men vaststellen dat er een evenwicht is? De wetgever is bewust terughoudend om het subjectieve begrip 'evenwicht' juri-

57 A.L. Verbeke, Mediation van opvolging in familiebedrijven, in: De ervaren mediator: kwaliteit, identiteit en ethos, Antwerpen: Maklu 2012, p. 31-39.

58 A.L. Verbeke, M. Euwema \& K. Bollen, Familiale grammatica, Antwerpen: Intersentia 2020, p. 118-119.

59 A.L. Verbeke, Erfenisruzies en procedures anticiperen door family governance, in: Het familiebedrijf en de nalatenschap, Erfenisvakdag Cahier 4, Antwerpen: Maklu 2015, p. 77-87.

60 R. Dekkers, H. Casman \& A.L. Verbeke, Erfrecht en giften, Antwerpen: Intersentia 2018, p. 287-296. 
disch te omschrijven. ${ }^{61}$ Het zijn immers de partijen zelf, en zij alleen, die moeten bepalen in de akte hoe zij dit evenwicht hebben opgevat en aanvaard. ${ }^{62}$ De notaris kan en mag dus niet zijn eigen visie of perceptie van wat een evenwicht zou zijn aan de partijen opdringen. ${ }^{63}$

Dit gebrek aan objectief inhoudelijke bewaking van het evenwicht vormt een groot risico van misbruik bij een globale erfovereenkomst. Familieleden zouden onder druk van de omstandigheden kunnen instemmen met en toegeven aan een evenwicht dat ze niet ten volle vatten. Een globale erfovereenkomst is niet zomaar een gewoon contract. Het is een duurovereenkomst met zware gevolgen op lange termijn. Men gaat een verbintenis aan ten aanzien van een niet opengevallen nalatenschap. Daarbij verbindt men zich nu voor gevolgen die pas veel later zullen optreden en zich dus ook veel later zullen laten voelen.

De wetgever voorziet in procesmatige beschermingsformaliteiten (art. 1100/5 BW), met het vereiste van notariële akte, voldoende bedenktijd door opdeling in drie fasen van (1) ontwerp, 15 dagen later (2) een informatievergadering en 1 maand later (3) het ondertekenen van de akte, en ook de mogelijkheid van een eigen raadsman en individueel onderhoud met de notaris. ${ }^{64}$ Maar dit is niet voldoende.

De GEO biedt een uitgelezen mogelijkheid voor bemiddelaars om een familie te begeleiden in het zoeken naar het evenwicht. Voordat een ontwerp kan worden opgemaakt, is een dialoog nodig waarbij iedereen aan bod komt en men samen dat evenwicht kan bepalen. Dat is niet gemakkelijk en vergt professionele begeleiding. En ook als er een ontwerp is, is het belangrijk om de toestemming van eenieder te double checken. Is er een echt vrije toestemming en akkoord? En beseft die partij echt wat hij of zij doet, vat hij of zij de volle draagwijdte van dit akkoord, niet enkel nu, maar ook binnen twintig of dertig jaar als papa of mama komt te overlijden? Deze dubbele of versterkte toestemmingscheck kan de bemiddelaar doorvoeren in een een-op-een onderhoud met elk van de partijen. ${ }^{65}$ Hierbij maken we een onderscheid tussen het wat en het hoe van deze check. ${ }^{66}$

\section{- Het 'wat'}

De bemiddelaar doet een dubbele check, van zowel de vrije toestemming in het heden, als het besef van de draagwijdte van die toestemming in de toekomst. Hij moet zich ervan vergewissen dat een partij niet enkel begrijpt waarover het gaat, en daarin

61 Advies Raad van State, Parl.St. Kamer 2016-2017, nr. 54-2282/002, 33.

62 A.L. Verbeke \& M. Delbroek, Family dynamics en het evenwicht bij de globale erfovereenkomst. In: Themis familiaal vermogensrecht, Cahier 109, Brugge: die Keure 2019, p. 75-97.

63 A.L. Verbeke m.m.v. K. Bollen \& T. Besieux, De notaris als procesbewaker bij het zoeken naar een evenwichtige globale erfovereenkomst, in: Notariële actualiteit 2018-2019, LNG 21, Antwerpen/ Cambridge: Intersentia, p. 55-75.

64 H. Casman \& A.L. Verbeke, Formaliteiten van een (globale) erfovereenkomst: een teleologische interpretatie, Tijdschrift Estate Planning - TEP 2018, p. 379-386.

65 Ook de Raad van State stelt dit voor als een mogelijke piste (Advies van de Raad van State nr. 60.998/2 van 20 april 2017, Parl. Doc. Kamer 54 2282/002, 33 medio). Een andere formule die de Raad van State vermeldt, is de verplichte bijstand door een raadsman, notaris of advocaat.

66 A.L. Verbeke m.m.v. K. Bollen \& T. Besieux, De notaris als procesbewaker bij het zoeken naar een evenwichtige globale erfovereenkomst, o.c. 
vrij en zonder dwang of druk toestemt, maar ook dat deze de volle draagwijdte van het gebeuren beseft, niet enkel nu, maar ook in de toekomst. Hij geeft best een paar realistische toekomstscenario's en gaat na of partijen beseffen dat wat ze nu tekenen en de verregaande gevolgen daarvan zoals verzaking aan inbreng en inkorting, ook nog in die situaties in de verre toekomst zal gelden, en of ze zich daar nog steeds goed bij voelen.

- Het 'hoe'

De bemiddelaar beperkt zich uiteraard niet tot het stellen van een aantal vragen, waarop de partij met een simpel 'ja' of 'neen' kan antwoorden. Daarmee kan men hoegenaamd niet inschatten of de partij ten volle vat wat zij zal ondertekenen. Dit kan enkel als de partij zelf in haar eigen woorden toelicht waarover de akte in essentie gaat en waartoe zij zich verbindt. Deze toelichting moet zowel over het nu gaan, als over de gevolgen van de toestemming op langere termijn en bij overlijden van vader of moeder.

1 Stel open vragen, waardoor je peilt naar de gevoelens en onderliggende belangen van elke partij en of die voldaan zijn.

2 Doe de volle draagwijdtecheck door concrete voorbeelden en scenario's over twintig of dertig jaar in kaart te brengen.

3 Nodig de partij uit om aan te geven wat ze graag anders of veranderd ziet en waarom.

4 Houd notities bij in een dossier.

5 Ga niet voor een ja/nee check bij het ondertekenen van het contract, maar nodig elk familielid uit om de inhoud van de overeenkomst in zijn of haar eigen woorden uit te leggen.

In overleg wordt er een familiale planning uitgewerkt waarbij de aandelen gelegateerd worden aan Marleen en Arthur, en minimaal aan Clément. Daar waar Marleen en Arthur een (operationele) rol zullen innemen in het familiebedrijf, zal Clément enkel in het bestuur zitten van een aantal organen. Daarnaast zullen de schilderijen allemaal naar Clément gaan. Dit is een stevige duw in zijn rug om zijn droom te vervullen om een eigen kunstgalerij te openen. Het feit dat zowel André als Julie heel regelmatig voor de kinderen van Marleen zorgen en helpen in het huishouden wordt mee opgenomen voor het bepalen van het evenwicht van de globale erfovereenkomst.

\section{Besluit: als familie anticiperen en investeren in de toekomst}

Het ligt in de Vlaamse aard om moeilijke gesprekken uit de weg te gaan. Zeker wanneer het duidelijk is dat vader of moeder binnen afzienbare tijd zal overlijden, valt het voor de kinderen erg zwaar om hun ouders hierover te bevragen. Als ouder probeert men dit vaak eenzijdig te ondervangen door een juridisch fiscale planning op te stellen, zonder of met zeer symbolische inspraak van de familie. 
De effectieve vervulling van dergelijke planning bij overlijden van een van de ouders, of na overlijden van beide ouders, lijkt dan vaak op het gevaarlijk openen van een doos van Pandora.

Als familie anticiperen op het onvermijdelijke, is elkaar de ruimte geven om op een gerichte manier met elkaar in gesprek te gaan: Wat betekent dit verlies voor onze familie? En wat is er nodig om de drie sferen van de familie, namelijk de privérelaties, de bedrijfsbelangen en het vermogen goed te organiseren en continueren? Binnen een familie(bedrijf) is het niet steeds eenvoudig te achterhalen wat eenieders wensen, belangen en verlangens zijn. Vlaamse families zijn qua leiderschap nog steeds gehandicapt door het baronsyndroom, met een hiërarchie waarbij de pater familias het gewoon is dat naar hem wordt geluisterd en waarbij de andere familieleden weinig inspraak krijgen en de beslissingen lijken te aanvaarden. In werkelijkheid groeien spanningen en frustraties, waar de familieleden, eenmaal de bom barst, niet mee kunnen omgaan. ${ }^{67}$

Daarom is het van belang dat de familie in haar geheel en elk familielid afzonderlijk conflictvaardigheden aanleert. Dit is ingebed in een ruimer leerproces van open, transparant en empathisch communiceren met elkaar. Om als individu en familie te leren, zijn feedback en reflectie van belang. Daarbij kan een bemiddelaar of facilitator enorm helpen, voor zover hij of zij beschikt over de nodige vaardigheden uit gedragswetenschappelijke disciplines. Zijn taak is gericht op het faciliteren van het proces dat de familie zelf in de hand heeft. ${ }^{68}$ Naast de vereiste sociale vaardigheden die de bemiddelaar/facilitator moet bezitten, is het uiteraard cruciaal dat de uiteindelijke planning juridisch en fiscaal solide is. ${ }^{69}$ Als familie werken aan een groeiproces, doet men dus best onder begeleiding van een multidisciplinair team van psychologen én juristen.

67 A.L. Verbeke, M. Euwema \& K. Bollen, Familiale grammatica, Antwerpen: Intersentia 2020, p. 87-89.

68 Ibid., p. 93.

69 A.L. Verbeke, Bemiddelen voor het geschil: Family Governance, TPR - Tijdschrift voor Privaatrecht, 2014, p. 969-983. 